\title{
Return to work or job transition?: Employer dilemmas in taking social responsibility for return to work in local workplace practice
}

Ida Seing, Ellen MacEachen, Kerstin Ekberg and Christian Ståhl

\author{
Linköping University Post Print
}

\section{Tweet}

N.B.: When citing this work, cite the original article.

Original Publication:

Ida Seing, Ellen MacEachen, Kerstin Ekberg and Christian Ståhl, Return to work or job transition?: Employer dilemmas in taking social responsibility for return to work in local workplace practice, 2015, Disability and rehabilitation, (37), 18-19, 1760-1769.

http://dx.doi.org/10.3109/09638288.2014.978509

Copyright: Informa Healthcare

http://informahealthcare.com/

Postprint available at: Linköping University Electronic Press

http://urn.kb.se/resolve?urn=urn:nbn:se:liu:diva-112397 


\section{Authors of the article:}

Ida Seing, Ellen MacEachen, Kerstin Ekberg, Christian Ståhl

\section{Title of the article:}

Return to Work or Job Transition? Employer Dilemmas in Taking Social Responsibility for Return to Work in Local Workplace Practice

\section{Affiliations and addresses of the authors:}

Ida Seing (Corresponding author)

National Centre for Work and Rehabilitation, Department of Medical and Health Sciences, Linköping University, 58183 Linköping, Sweden

E-mail: ida.seing@liu.se

Telephone: +46 (0)10-1034963

\section{Ellen MacEachen}

Department of Public Health and Health Systems, Faculty of Applied Public Health, University of Waterloo, Ontario, Canada

\section{Kerstin Ekberg}

National Centre for Work and Rehabilitation, Department of Medical and Health Sciences, Linköping University, 58183 Linköping, Sweden

HELIX VINN Excellence Centre, Linköping University, Linköping, Sweden

\section{Christian Ståhl}

National Centre for Work and Rehabilitation, Department of Medical and Health Sciences, Linköping University, 58183 Linköping, Sweden

HELIX VINN Excellence Centre, Linköping University, Linköping, Sweden

Key words: Employers, workplace, activation policy, sick leave, work accommodation 
Purpose

The aim was to analyse the role and activities of employers with regard to return to work (RTW), in local workplace practice.

Method

Semi-structured interviews were conducted with sick-listed workers and their supervisors in 18 workplaces $(n=36)$. The analytical approach to study the role of employers in RTW was based on the three-domain model of social corporate responsibility. The model illustrates the linkage between corporations and their social environment, and consists of three areas of corporate responsibility: economic, legal and ethical.

Results

Employers had difficulties in taking social responsibility for RTW, in that economic considerations regarding their business took precedence over legal and ethical considerations. Employers engaged in either 'RTW activities' or 'transition activities' that were applied differently depending on how valued sick-listed workers were considered to be to their business, and on the nature of the job (e.g. availability of suitable work adjustments).

\section{Conclusions}

This study suggests that Swedish legislation and policies does not always adequately prompt employers to engage in RTW. There is a need for further attention to the organizational conditions for employers to take social responsibility for RTW in the context of business pressure and work intensification. 


\section{Introduction}

A critical task of social policy in most Western welfare states during recent decades has consisted of reducing the economic burden to society due to sick leave, by stimulating participation in the labour market. Many jurisdictions have introduced activation policies, based on the premise that 'work per se' has a therapeutic function in terms of leading to good health and well-being for sick-listed workers [1, 2]. Getting people on sick leave back to work before they have fully recovered is presented as rather unproblematic. The focus is on early return to work and people are expected to be 'active', instead of 'passive' recipients of financial benefits $[3,4]$. In line with this development, employers and the workplace have come to play a direct or indirect key role in the return to work (RTW) of sick-listed individuals. The focus in social policy on employment promotion rather than on systems of social protection reflects a strong belief that employers and the labour market have the ability to solve society's problems of sickness absence.

The importance of early-return-to-work measures to ensure individuals' health and work ability is also reflected within the research field of work disability prevention (WDP). Systematic reviews of return-to-work interventions identify how early rehabilitation and early contact with the workplace during the employee's sick leave facilitate $\operatorname{RTW}[5,6]$. Modified work facilitates workers' return to work and reduces the number of lost work days [7], and supervisory training in communication skills and ergonomic adjustments reduces the number of new injury claims [8]. However, most studies of return-to-work have been of planned interventions, usually with willing work organizations and employers. Therefore, an understanding of natural RTW conditions is unclear. Further, past intervention studies of RTW have adopted different definitions of RTW in terms of time period (e.g. return for a 
short or longer period of time), different ideas regarding what 'work' the sick-listed people are returning to (e.g. former job or new workplace setting) [9]. Hence, an understanding of how RTW plays out in natural conditions is scarce and a common definition of what constitutes 'return' and 'work' remains elusive $[9,10]$. There is emerging research on the complexity of multi-stakeholder involvement, showing how employers and workplaces influence the practice of RTW [11-18]. Studies have analysed supervisors' perspectives and attitudes to sickness absence, RTW, and what is needed to facilitate job retention $[11,18]$. To avoid long-term sickness absence and promote sustainable RTW, the importance of clear company policies is underlined. Furthermore, the need for early contact and regular communication between supervisor and sick-listed employee, as well as multi-stakeholder collaboration is highlighted [11-14]. Research has also shown that lack of clear local policies for managing early return to work may result in solutions based on expense avoidance rather than on rehabilitation to work when employers tend to focus on their own business and production logic [19].

How employers in practice deal with and manage the RTW of sick-listed employees is still a relatively uninvestigated and under-theorized research area. The body of research is limited regarding the organizational conditions for employers to take social responsibility for RTW in a modern workplace context. Both social activation policies and WDP research reflect a rather idealized view of a standard workplace, in that there is an explicit or implicit assumption that workplaces and employers are able and willing to welcome sick-listed workers in a healthy way [3]. In the light of current social activation policies and WDP research emphasizing the importance of activation and early RTW, this study focuses on the role and activities of employers in the return-to-work processes of sick-listed workers. 


\subsection{Aim}

The aim of this study was to analyse the role and activities of employers with regard to RTW, in local workplace practice. Special focus is on how economic, legal and ethical considerations influence their willingness and ability to engage in RTW activities.

\section{Conceptualizing Employer Activities in Return to Work}

This study takes its point of departure in the assumption that organizations are open systems which are strongly influenced by their social environments. Against this background, a suitable analytical approach to study employers' activities in RTW is the three-domain model of social corporate responsibility (CSR), which conceptualizes the linkages between corporations and their social environment [20]. According to Schwartz and Carroll, CSR activity consists of three areas of corporate responsibility: economic, legal and ethical. Activities may be based on purely economic, legal or ethical interests; the three different domains may also overlap and simultaneously influence the activities. The economic domain refers to corporation activities where the aim is to maximize profits and economic benefits. From this perspective, employer behaviour/activities (decision-making and organizing) take place based on economic interests and business needs. Activities falling into the legal domain involve corporate actions that occur due to the existence of a law, i.e. regulations and policies that influence corporations' frameworks for action. In the context of RTW, legal demands might for example consist of regulations regarding the formal obligation of employers to engage in the RTW of their sick-listed employees. Corporations' 
compliance with the law may be passive (i.e. non-reflected), restrictive (i.e. actions that would not have been carried out without the law) or opportunistic (e.g. making use of loopholes in order to engage in certain activities). The ethical domain involves different forms of 'voluntary' activities of corporations that are performed based on a set of ethical and moral principles in society, and are expected by a general population and stakeholders. In a Swedish RTW context, local collective agreements between employers and unions regarding RTW and health and safety might be an example of corporation activities that have been voluntarily accepted by the employers.

This study used the three-domain model (Figure 1) as an analytical tool in order to conceptualize, analyse and illustrate the role and activities of employers regarding RTW, in the context of workplace supervisor-worker relationships.

Insert figure 1 about here

\section{Methods}

\subsection{Study Setting}

The main actor in Swedish sickness insurance is the Swedish Social Insurance Agency (SSIA), which is a governmental authority responsible for administrating and coordinating sickness insurance and return to work. Meanwhile, a large number of other organizations, professions and disciplines are involved in this process, mainly physicians and rehabilitation professionals in primary or occupational healthcare, employers, the Swedish Public 
Employment Service and municipalities. These stakeholders all have different tasks and responsibilities in the return-to-work process of sick-listed individuals.

The responsibility of the employer in the RTW process is explicitly regulated in two laws in Sweden: the Work Environment Act and the Social Security Act. There may also be local collective agreements between employers and unions at workplaces that regulate RTW. According to the Social Security Act, the employer is required to provide the Social Insurance Agency with relevant information, after consultation with the worker, in order to identify the worker's rehabilitation needs as early as possible. The employer must also ensure that all necessary measures are taken for an efficient rehabilitation [21]. According to the Work Environment Act, employers have a jurisdictional duty to organize workplace adjustments and rehabilitation activities for workers on sick leave in an "appropriate way" [22]. The instructions in the law stress that work tasks are to begin as early as possible. The employer must clarify how work adjustments and rehabilitation are to be carried out, and those who are responsible for these questions must have the knowledge and competence that is needed. It is further underlined that activities are to be organized in cooperation with the employee and a representative of work environment issues. Employers' activities must also be designed so that cooperation between the Swedish Social Insurance Agency and other relevant authorities can be established. It is further stated that the employer is required to adjust the work situation based on the worker's conditions to work, paying particular attention to whether the worker has a disability or reduced work ability [23]. In specific cases, the Swedish Work Environment Authority (carried out by inspectors) may inspect how the employers are fulfilling their obligation in return to work. Employers who are considered not to comply with the regulations may be imposed with a penalty [24]. 
However, the legislation can be described as a soft law which is openly formulated and in practice leaves considerable room-for-manoeuvre for employers to determine how RTW activities are to be performed and organized [24]. The legislation is also described as taking account of implicit economic considerations for the employers' business in terms of an understanding that workplace adjustment cannot take place if it is financially indefensible for the employers - which must be assessed based on the employers' resources and conditions [24]. In Sweden, employers' cannot terminate an employment due to a disease. However, if the disease is permanent and will prevent an individual from performing any task of importance of the employer, and if the employer has extent all their recourses in trying to accommodate and rehabilitate the injured worker in the first 6 months of sick leave, a dismissal is possible [25].

The employer is responsible for sick pay, which must cover $80 \%$ of the worker's salary, for 14 days. After this period, the Social Insurance Agency assesses the person's work ability to determine whether he or she is eligible for sickness benefits on the basis of a medical certificate [25]. In line with activation polices based on the logic of early return to work [3], the focus of policy-makers in Sweden during the last decade has been on the reformation of the social security system and strengthening the work principle in general [26-28]. With the aim of reducing the number of people on sick leave, it has become increasingly difficult for individuals to qualify for sickness benefits. Replacement rates in sickness insurance have been correspondingly reduced [28]. At the policy level, the increased responsibility of the individual for his/her return to work has been clarified: 
The insured person should have greater responsibility than previously for his/her work ability, and should take the initiative and ask for measures at the workplace which may result in him/her being able to return to work. [29] (proposition 2007/08:I36, page 64)

At policy level, it is also apparent that sick leave is considered the start of a 'transition process' - from sick leave to a new job or unemployment. Job transition is described in positive terms; changing jobs is seen as a solution to sickness absence, in that a better 'match' or 'fit' between the sick-listed individual's work ability and existing jobs on the labour market is expected to be achieved.

[I]t is important that sick leave becomes the start of a transition process. In successful cases, there can be a direct transition from sick leave to a new job, and in other cases a period of unemployment may be required before the goal is reached. In all cases, transition is preferable to continued sick leave and ultimately disability pension. The task of the insurance systems is to facilitate transition [...] [30] (SOU 2006:86; page 62)

In the light of this development, the so-called rehabilitation chain was introduced in the sickness insurance system in 2008 , based on stricter activating principles comprising an endpoint of entitlement to sickness benefits. After the initial 14 days of employer responsibility (day 15-180), work ability (and entitlement to sickness benefits) is assessed in relation to work tasks with the same employer. After 180 days (day 181-365), the assessment is broadened to include work ability in relation to the labour market at large. It is thus possible that sickness benefits may end after six months if a person is considered able to work in another job. During the first year, sickness benefits are set at approximately $80 \%$ of wages; after 365 days, prolonged benefits for an additional 550 days may be granted, with a $75 \%$ replacement rate. After this period, a labour market introduction programme is offered by 
the Public Employment Service. The programme lasts for a maximum of three months, after which it is once again possible to apply for sickness benefits $[25,31]$.

The rehabilitation chain implies a focus on employers' duties and possibilities to offer work adjustments or other work tasks in line with employees' work ability during the first 180 days of sick leave; however, this has neither been coupled with any increased legal responsibilities for employers, nor with increased control of the fulfillment of their duties.

\subsection{Participants and Data Selection}

This study is based on 18 sick-leave cases, where individual semi-structured interviews have been conducted with both the sick-listed workers and their supervisors separately in 18 workplaces in 2012-2013. The data material comprises a total of 36 interviews. The sickleave cases were purposively selected based on the length of the sick leave (more than 60 days) in order to include workers on long term sick leave. The median sick leave duration in Sweden is 50 days and the majority of the sick-listed workers return to work within 60 days $[32,33]$; those workers who are still on sick leave after this point are those at risk for long term sick leave and exclusion from the workplace. It is therefore important to study what measures that are taken for workers on long term sick leave in the workplace. Among the worker participants, the gender distribution was 16 women and two men; the supervisors consisted of 13 women and five men. The median age of the workers was 55 years and of the supervisors 50 years. Workplaces from 16 public organizations and two private organizations are represented. Regarding occupation, there were nine assistant nurses, one high school teacher, four public officers, one engineer, one legal specialist and one 
administrator (Table 1). Workers' diagnoses included a variety of physical and mental conditions.

Insert table 1 about here

Access to sick-leave cases was carried out in two steps. The first was to obtain a list of names of 20 people identified by the statistical unit at the Social Insurance Agency as sicklisted for more than 60 days. Letters were sent to these potential participants, informing them about the purpose of the study. They were ensured that participation was voluntary, and asked for permission to interview their employer. A consent form was enclosed with the letter, to be returned by the participants. Of 20 persons contacted, three agreed to participate. The other strategy for accessing people on sick leave was through employer and union representatives. Letters were sent to 16 representatives (13 employers and three union representatives) asking if they could identify workers who had been on sick leave for more than 60 days and who might be interested in participating in the study. Out of these, 5 representatives ( 1 union representative and 4 employer representatives) responded. They were informed about the study and that participation was anonymous in terms of person and work organization. Based on this request, representatives from employers (senior managers and human resource personnel) and unions identified and provided contact information for workers (and managers) who were interested in participating in the study. The interested sick-listed workers were contacted and informed about the purpose of the study; they were ensured that participation was voluntary, and asked for permission to interview their employer. A consent form was enclosed, to be signed by participants. In total, 15 participants were recruited through employers and unions. 


\subsection{Data Collection}

The method of data collection was semi-structured interviews, which made it possible to hold a thematic focus and compare interviews with each other. An interview guide was developed based on the purpose of the study. In order to get a rich material each participant was also given the opportunity to expand on issues they considered important. The interview guide covered broad themes including participants' views and experiences of causes of sick leave, the role of the workplace in return to work, and the importance of other relevant actors involved. A key ethical issue in the data collection was to avoid the risk of spreading confidential information between the two parties in each case. In all cases, the interviews with the worker were conducted first and the supervisor interview followed. The time lapse between the interview with the worker and their supervisor varied from around 1 week to 3 months. The interviews, which lasted from $45 \mathrm{~min}$ to over two hours, were conducted by the first author. All interviews were conducted during personal meetings in public libraries, university facilities, workplaces and cafés. The interviews were conducted in separate rooms and spaces where only the participant and the interviewer were present and could hear the dialog. They were digitally recorded and transcribed verbatim. Minor corrections in citations have been made to improve readability.

\subsection{Data Analysis}

A qualitative content analysis of the interviews was carried out. The study examined manifest and latent content of the material, focusing on both the visible components and the underlying meaning of the text $[34,35]$. The analysis process was performed in several 
steps during which the authors regularly discussed the categorization of the material. Initially, the first author read through the interview transcripts several times in order to get a sense of the material as a whole, which generated broad descriptive categories such as the nature of work, the process of sick leave, experiences of activities in RTW, and the role of the welfare system. In the next step, a theoretical model was identified to guide a more directed content analysis [36], where employer activities were categorized from economic, legal and ethical perspectives. From this model, the descriptive categories were mapped in relation to the theoretical concepts, and quotations were added in order to illustrate how these perspectives influenced employers' activities in RTW. This process was iterative in character, with data and theory dialectically influencing the analysis.

\subsection{Ethical Considerations}

The study was approved by the Regional Ethics Board in Linköping, Sweden. Basic ethical principles concerning informed consent, confidentiality and not causing harm to participants were taken into account.

\section{Results}

The material was analysed based on the theoretical model of CSR, where employers' activities are related to the influence of economic, legal and ethical considerations, and how these interact. Therefore, the results are presented following the intersections between the economic, legal and ethical domains. Employers' activities in RTW were seen to be related to overlapping economic, legal and ethical domains. However, the economic domain was generally dominant; it was the needs and interests of employers' businesses that guided their role and activities in the RTW process. Employers engaged in either 'RTW activities' or 
'transition activities' that were applied differently, depending on how valued the sick-listed workers were considered to be to their businesses and the nature of the job (e.g. availability of suitable work adjustments). Legal demands had little practical influence on employers' RTW strategies, since these could support both RTW and transition approaches.

\subsection{The Economic-Legal Intersection}

Particularly in low-wage jobs, where the workers were considered easy to replace, the economic logic of employers' RTW activities was expressed as difficulties in adjusting the workplace due to business pressure. Supervisors emphasized that they had a regulative obligation to make adjustments but that they had to primarily think about their business and they could not invent jobs or work tasks that were not needed; they saw it as necessary for workers to have full work ability if they were to return. Workers and supervisors frequently described current working life in terms of increasingly high performance demands, and they stressed how this resulted in limited latitude for people with reduced work ability. Several supervisors expressed that the SSIA ought to have a better knowledge of current workplace conditions and accept that work adjustments are not possible. One supervisor stressed the importance of not falling into the SSIA's 'trap' and being forced to accommodate a sick-listed worker; one strategy was to make clear from the beginning that work adjustment was not an option. Thus, employers resisted by referring to business needs and thereby managed to avoid legal pressure to adjust the workplace in line with the workers' needs.

I mean, the Social Insurance Agency is really happy if I create an adjusted post for someone. So, as an employer it's important not to fall into that trap, if you know what I mean, since I don't actually have the money for adjusted posts [...]. (Case 14, supervisor, elderly care) 
In several cases, work ability was often seen as an individual question, and the worker's physical and mental condition was formulated as constituting the main problem for sick leave and creating barriers for RTW. Particularly in low-wage jobs, reasons for sick leave were primarily found in the functional limitations of the workers rather than their work environment.

[...] I mean, it just seems like so unfair, that no matter what sort of job we have, some bodies just get worn out faster. [...] Well, nobody really knows why it's like that. I suppose it's like with cars: some of them last five years, others last ten. (Case 4, supervisor, hospital) Both supervisors and workers emphasized the strong focus on effectiveness at their workplaces, where keeping to the budget was the main priority. They described how the psychosocial work environment had become more stressful due to cutbacks, reorganizations and redundancies. Their illustrations of work intensification at workplaces included high workload and a high degree of employee turnover, and also the fact that there had been many changes of supervisors in their work organizations. Supervisors described themselves as being in the middle, between demands from above (politicians and management) and below (workers), and how these demands sometimes collided.

No, as I see it, in the nineties sometime, that's when the re-organizations began [...]. And now there's been re-organization after re-organization. And I feel that they never really evaluate how it went or so. They just start a new one. (Case 8, supervisor, elderly care)

In low-wage jobs, where the workers were considered to be replaceable, activities were characterized by 'transition activities' in terms of workplace measures aimed to transfer the worker away from their original job. Sick-listed workers were encouraged to relocate to another job at the workplace, to quit or to retire. In these situations, relations between the 
supervisor and the worker were frequently characterized by distrust. In cases where the focus was on transition, the processes were marked by procedural correctness in terms of supervisors who frequently labelled these workers as 'rehabilitation cases'. Both supervisors and workers underlined how formal procedures such as 'rehabilitation investigations', 'rehabilitation meetings' and 'work ability assessments' had been conducted as prescribed by regulations. However, such activities rarely led to active RTW planning. When the focus was on transition, Human Resource (HR) departments could often be involved, by having a central function in employers' strategies to transfer sick-listed workers to new settings.

[Involving HR] That's when we see that it doesn't work and where I feel I've come to the end of the road. That I sort of need to find new opportunities. And more ways of thinking. Or when I see that I've got this employee and it just doesn't work with her in the job, and it will probably never work. How I plan for a good way forward for her, whether it's here or somewhere else. (Case 10, supervisor, public authority)

Employers' focus on transition was supported by the early-return-to-work policy stipulated by law, to which they could refer in order to legitimize their actions. Supervisors motivated job transition in terms of a 'healthy change' and 'new opportunities' for sick-listed workers. The sick-listed worker was also required to take responsibility and not expect that he/she had a right to return to work. Workers should instead be entrepreneurial and look for another job on the labour market.

This is something that I also sense in society: that no one wants to change their job. It's not so easy to change jobs in Sweden; everyone wants to hold onto a permanent post. [...] this means that lots of people are very unhappy at workplaces [...] But I mean that's where you have to 
take responsibility yourself and say sort of "I don't like it here, I've got to change jobs" or whatever. (Case 5, supervisor, public authority)

While supervisors described transition in positive terms, sick-listed workers regularly experienced the process as painful and unjust. In several cases, the workers emphasized how they had been forced by the employers to change workplace (work relocation) against their will, and how they were excluded from the decisions regarding RTW. Workers often felt social and emotional attachment to their original jobs, especially when they had been employed for many years. They frequently underlined how much they liked their work tasks and co-workers, and how these jobs provided security.

I got to know the same day I came back from sick leave: "Listen, you're going to start at [new workplace] on the 15th of October". Then I was completely stunned and I said I didn't want to. [The supervisors said]: well, that's the way it is, and we hope you'll adjust". (Case 11, worker, assistant nurse)

Long-term employees considered that they had the right to keep their present job, with work adjustments made there if necessary. They believed that their employer 'owed' them the job that they had managed to perform successfully for many years. Workers expressed feelings of lost dignity and betrayal by the employer. They also tended to see change as a downgrade in the quality of their job, and felt they were placed at another work unit or quit because they were not considered sufficiently productive at their current job. They also doubted their 'employability' on the labour market and the willingness of other employers to hire individuals with reduced work ability and a history of sick leave. 
[The employer says:] Quit work, quit work. [...] I mean, there isn't anything else. They have nothing to offer, and who wants to hire a person at the age of 60? No one. I haven't got a chance on the labour market today, that's just the way it is. (Case 11, worker, assistant nurse)

In contrast to these cases, there were others for whom the return to work from sick leave went smoothly, where employers actively focused on RTW rather than transition. In these cases, supervisors regularly expressed how irreplaceable the workers were in terms of being efficient, responsible, cooperative, and having unique competences. The jobs these workers did were often highly skilled, and characterized by flexible working conditions with inherent possibilities for adjustments.

I've always thought that we have nothing to gain by letting him be sick-listed. Because we have the staff we have. You can't go to the Public Employment Service and get a legal specialist who can just step in on Monday. It doesn't work like that. (Case 2, supervisor, public authority)

The workers considered to be valuable were involved in the design of work adjustments, they got reduced workload, and were offered flexible work schedules to fit their current work ability. In these cases, the SSIA often had a limited role in their contact with the workplace. Instead of 'procedural correctness', employers' measures were to a large extent characterized by flexibility, and the sick-listed workers saw themselves as having an influential role.

We talked on the phone and we met, a little bit like that, not so structured or documented, but that's the sort of communication climate we have with [worker] - I have great confidence in him and hopefully he has that for me. Well, yes, I think he has. (Case 1, supervisor, private transport/infrastructure company) 
Overall, the analysis shows that the economic domain was given priority, in that it was generally possible to adjust the legal demands to business needs: both RTW and transition activities complied with legislation. However, the activities differed depending on the nature of the job and how valued the employer considered the sick-listed workers to be.

\subsection{The Legal-Ethical Intersection}

Employers' activities could be based on legal and ethical considerations simultaneously. These activities were common in cases where supervisors considered that the worker was in poor health and returned to the workplace too early. Some supervisors expressed concerns regarding the financial insecurity of sick-listed workers and described how worries about not being entitled to sick-leave benefits had a negative impact on their employees' RTW. In these situations, supervisors expressed feelings of empathy with the worker. Meanwhile, adjustments were often not considered possible due to medical conditions or business pressure.

I mean I suffer with her of course, and think it's really tragic that she probably won't manage to come back. (Case 8, supervisor, elderly care)

In these situations, supervisors could support sick-listed workers in their contacts with SSIA officials and doctors by phone or meetings, in order to follow up the worker's sick leave. They could also try to convince doctors and the SSIA that is was impossible for the worker to return to work due to lack of health and severe illness. In this context, it became clear how an 'alliance' between the supervisor and the worker against both the doctor and the SSIA could be developed. These situations reflected how employers tried to push the responsibility for RTW back to the SSIA and the healthcare system, based both on the social concerns of the worker and the needs of the business. 
Yes, I've had really good relations with my employer. [...] I mean, she has been with me to the Social Insurance Agency. [...] and now she's also phoned the Social Insurance Agency on my behalf to check what's going to happen now and so on. She phones me and she's even sent me a [work] schedule although she knows that I won't be on that. (Case 8, worker, assistant nurse)

A few sick-listed workers experienced how employers' contacts and activities were based on ethical concerns for their health and well-being, and not only due to economic interests. In these cases, workers emphasized how they experienced that their employer genuinely wanted them back and that they were valued at the workplace.

During sick leave I had regular contact with both the supervisor and my co-workers who supported me well and wanted me back, but not in a stressful way. I knew they had a lot to do, but I never felt any pressure that I had to come back because we have so much to do. It was more "come back, we miss you" and "come back as much as you can and when you can". (Case 2 , worker, legal specialist)

Meanwhile, the analysis illustrates how workers' positive experiences were related to their value to their employer. Here the social relations between workers and supervisors were good and harmonious, and in these cases, legal and ethical considerations coincided.

\subsection{The Economic-Ethical Intersection}

A number of cases reflect how employers' activities in RTW were based on economical and ethical considerations simultaneously. The employers conducted these activities despite the fact that there was no legal obligation for them to do so. In one case the supervisor emphasized how she had allowed the sick-listed worker to produce less than $100 \%$, although he was employed and received $100 \%$ wages. The supervisor was sensitive to the 
worker's needs but stressed that in the end a social approach would benefit her as an employer as well. The supervisor considered the worker to have a business value to the workplace in terms of possessing a unique function and competence.

If I say this is $100 \%$, this is what you've got to do, and he does $80 \%$, well that's much better than if he's at home on sick leave. Hopefully for him, and better for us too, because then $80 \%$ will be done at least. [...] instead of just saying: "Ok, I hear that you're sick but you've got to deliver 100\%". Well, in that case the person won't turn up on Monday morning. (Case 2, supervisor, public authority)

In another case the supervisor considered that the sick-listed worker was inefficient and did not have the right attitude in dealing with customers. However, the supervisor knew that the worker would retire shortly and that she was appreciated among the co-workers, so she decided to "let her be" and allowed her to perform the work tasks in her own way. Thus, the worker could finish her work with dignity, according to the supervisor.

She's a happy elderly lady and she bakes delicious cakes on Fridays. And in that way she brings warmth and joy to the group. If I hadn't known that she was going to retire soon, I would have worked with her in a completely different way. But now l've let her be. She can be who she is, and that's perfectly okay. She contributes as much as she can and that's good enough. (Case 10, supervisor, public authority)

A few cases demonstrate how employers' RTW activities occurred because their actions were considered to be morally and ethically correct. These activities took place in cases where the sick leave had been caused by a workplace accident or when the employer had misinterpreted SSIA regulations. In one case, the employer decided to provide sick pay for a period after the worker had had her benefits from the SSIA withdrawn, and also found 
suitable work adjustments. In this case it was particularly clear that the employer took social responsibility and showed ethical concerns for the sick-listed worker.

When she [sick-listed worker] understood that, "No, I'm not going to get any money", she was forced to do something about her situation. So she calls me and tells me that. Then we had to go to the Human Resources people directly, and the union, to find the solution. So then the municipality [the employer] intervened and paid sick pay, so she was sick but she got sick-leave benefit from the municipality [employer] and that's not what normally happens, but I suppose it was sort of an individual solution for this. (Case 18, supervisor, social care)

The material also reflects how RTW activities would only be an option if employers wanted the sick-listed worker back. For example, one supervisor stressed that he put more effort into accommodating sick-listed workers whom he knew were efficient, took responsibility, could cooperate and had a good attitude at the workplace.

Of course, if it's a person you don't want back, it always turns into a budget issue that we can't afford to do things. But for the people we want back, I think I try to make sure that we can do things. (Case 5, supervisor, public authority)

The fact that employers invest more resources in valued workers who they really want back was also stressed by sick-listed workers; it was clear that ethical concerns were related to economic considerations.

The employers only make an effort if the worker has a special competence that they can't do without. But not for us ordinary workers - no, we can be replaced: "No, so what? I'm an assistant nurse, there are many more waiting in line. Just bring in a new one." [...] It costs money if they [employers] have to make adjustments in work tasks so that someone can come 
back. [...] So they don't care, there are new ones waiting in line. (Case 17, worker, assistant nurse)

Overall, activities in the intersection of the economic and ethical domain were voluntary in character and took place without legal obligations.

\section{Discussion}

This study illustrates how employers had several difficulties in taking social responsibility for RTW; and that economic considerations for their business took precedence over legal and ethical considerations. Current legislation had a limited practical impact on employers' activities in RTW, since these could support both RTW and transition, and involvement in formal RTW procedures could legitimize the decisions of employers not to provide suitable adjustments for sick-listed workers.

\subsection{Understanding Employers' Activities in Return to Work}

Employers' RTW activities could be related to the economic, the legal and the ethical domain. While the activities often represented overlaps between these domains, the economic domain was generally dominant (as illustrated in Figure 2). Hence, the results of this study illustrate that the employers' approach to sick-listed workers was dominated by business needs that influenced their role and activities in RTW. In low-wage jobs, where the workers were considered to have a low value and be replaceable, there was an emphasis on transition of the worker from the original job. These activities consisted of transition measures or exit strategies [37] aimed to transfer/exit the sick-listed workers' away from their original job to another setting, such as work relocation, unemployment or retirement. 
The legal domain in Figure 2 is therefore placed entirely within the economic domain, since legal demands generally did not conflict with economic-driven decisions by the employers. Both of these approaches are favored in early-return-to-work policy and also by employers due to business pressure. The results also show that RTW activities were carried out in passive compliance with the law, and legislative pressure was not considered. Many of these activities would have taken place even if the legal requirement did not exist; hence, the activities can be considered to take place outside the legal domain [20]. Transition activities, on the other hand, were either carried out in restrictive or opportunistic compliance with the law [20] and actions were taken for a purpose other than the one stated in the legislation (legitimizing transition rather than facilitating RTW).

Employers' purely ethical considerations of sick-listed workers were rare. Instead, ethical activities were regularly linked to direct or indirect economic benefits for employers' businesses, or as a response to stricter regulations (early-return-to-work policy) [20]. For example, in cases representing high-wage jobs, where the worker represented a value to the employer's business, supervisors justified their activities along the lines that 'good ethics is good business' [20]. In low-wage jobs, where the worker had a low value to the employer, supervisors sometimes saw it as a form of 'social obligation' to support the worker in their contact with welfare-state actors and encourage them to take social responsibility for the worker. Employers who also promoted RTW for employees who were considered less valuable appeared to be prompted by a bad conscience, for instance if they felt responsible for the worker's injury. In Figure 2, the ethical domain reaching outside the economic domain illustrates this; generally, however, ethical concerns were taken into consideration when economically feasible. In these situations it became clear that employers 
'compensated' for the role of the welfare state by providing the worker with financial support or finding suitable work adjustments, although they were not required by law to do so.

Insert figure 2 about there

\subsection{Employers' Economic Perspective on Return to Work in the Context of Business Pressure and Work Intensification}

The results of this study reflected an intense and demanding working life, which affected the conditions for employers to take social responsibility for the RTW of sick-listed workers. The employers needed to balance societal expectations of taking responsibility for RTW with fulfilling the needs of their business. This tension between social responsibility and economic interests has been observed in previous research $[12,19,38-41]$. One study identified how employers experienced a conflict of interest between their formal role of implementing an early-return-to-work policy and their need to consider their production demands [39]. Other studies have shown how economic costs imply difficulties for employers to provide suitable modified work for injured workers [12, 41]. Small and medium-sized companies seem to put less financial resources into health and safety activities compared with larger corporations, whereas the latter tend to have a more generous approach regarding health and safety management, which enables work modifications; they generally have more work tasks to offer, and this allows employees with reduced work ability to work temporarily with tasks that are less demanding [42]. However, 
in this study even larger public work organizations had difficulties in offering workplace adjustments. For example, in cases where workers had a low value to the employers and where employers had difficulties in offering workplace adjustments, supervisors stressed that it was necessary for sick-listed workers to have full work ability when they returned to work. In several cases where work relocation was offered and discussed, sick-listed workers experienced that they were excluded and did not participate in the decision-making process concerning their RTW.

Employers' economic perspective on RTW can be understood in the light of changing working conditions in contemporary working life; research indicates that the trend over recent decades has been an increase in re-organizations, downsizing and redundancies. Working life is characterized by work intensification with high demands for productivity [4347]. In this context, so called new public management (NPM) reforms have been implemented in public sectors in several Western countries during the last few decades. With the aim to make public sector more efficient, measurements used in business, involving an increased focus on performance, output and customer orientation, have been introduced [48-50]. In Swedish work organizations, this development has involved an emphasis on cost-cutting and rationalization [2]. Meanwhile, previous research indicates how organizational restructuring may imply risks for the physical and mental health and well-being of workers [9]. For example, downsizing has identified to be associated with increased long-term sick leave among the remaining employees [51, 52].

The changes in working conditions also imply that the nature of employment contracts has changed, moving from employer-employee loyalty, predictability and stability towards flexibility and insecurity; particularly in jobs were the workers are considered replaceable. 
Employment contracts have become increasingly transactional in character and more market-oriented, based on the immediate value of individual workers and their production. The focus is on a market exchange, where workers have a set of skills that they want to deliver to the employer $[53,54]$. In the light of new employment relationships in modern working life, employers' different strategies for RTW become comprehensible. From this perspective, it becomes understandable why social responsibility is related to the immediate value of workers at the workplace, and why employers implement 'RTW activities' for workers who they consider valued and 'transition activities' for workers with a low value.

\subsection{Employers' Legal Role and Responsibility in the Return-to-Work Process}

Overall, the results of this study raise questions regarding the role and responsibility of employers in the RTW process. In a Swedish context, it is clear that the role of the welfare state has taken on a more controlling and administrative function; the main role of the SSIA today is to assess individuals' entitlement to sickness benefits. In the light of this development, there is an emphasis on the increased responsibility of the individual to be more active in the RTW process and ask for measures at the workplace $[29,30,55]$. Meanwhile, the results of this study illustrate the importance of the worker's value to the employer's business and the nature of work (e.g. availability of suitable work adjustments) for whether employers will engage in RTW activities. In cases where workers had a low value to the employer and where the focus was on transition, activities were often characterized by procedural correctness and formal rituals of what is prescribed in regulations. These workers had regularly gone through rehabilitation meetings, work ability 
assessments and rehabilitation investigations. However, such activities rarely led to active RTW planning; the focus was on legitimizing transition rather than facilitating RTW. Hence, current legislation on accommodating the worker was shown to have limited impact on employers' RTW activities; by engaging in formal procedures to clear responsibilities they could avoid the legal pressure to accommodate workers.

This result can be related to previous research which has identified a decoupling of what organizations say they do and what they actually do in practice $[56,57]$. According to these studies, organizations incorporate institutionalized elements (such as RTW policy, rehabilitation plans, work ability assessments, multi-stakeholder meetings, and rehabilitation coordinators/HR), which protect the organization from having their activities questioned [56]. From this perspective, employers' activities in RTW can be understood as 'rituals of legitimation' [58]. For example, by having an RTW policy for sick-listed workers, labelling the sick-listed worker as a rehabilitation case, involving $\mathrm{HR} /$ rehabilitation coordinators, and conducting rehabilitation plans and work ability assessments, the employers' decisions and activities are legitimized among actors in their environment such as the SSIA and the unions. This ritual process makes the activities trustworthy and justifiable, and in this way the employers' secure their survival and reduce the risk of having their actions contested [56].

The results suggest that Swedish legislation and policies may not always adequately prompt employers to engage in sick-listed workers' way back to work. In Sweden, the employer's legal responsibility regarding RTW of sick-listed employees has changed over time. In 1991, this regulative responsibility for RTW was expanded and legally clarified. Employers became 
formally obligated to investigate the rehabilitation needs of sick-listed workers and organize workplace adjustments and measures in order to stimulate return to work. The most significant change was the general requirement that employers were responsible for paying sick pay during the worker's first period of illness (14 days). These changes were designed to increase the incentive and willingness of employers to reduce the number of people on sick leave and to invest in the work environment to ensure workers' health [59]. In recent years policy-makers have primarily directed their attention to reforming the social security system to solve problems concerning sickness absence $[60,61]$ Meanwhile, less focus has been on strengthening the incentives for employers to promote RTW [62]. For example, the formal obligation of the employer to establish a rehabilitation plan was abolished in 2007. The main arguments behind this change were that rehabilitation plans contained insignificant information, and that the vast majority of employers did not conduct these investigations anyway [63]. Furthermore, employers are now underrepresented in Swedish cooperation structures regarding sick-listed persons' RTW [60].

Although Swedish employers have a legal responsibility to organize workplace adjustments and engage in RTW, it has been pointed out that the control of whether they are fulfilling their obligations is inadequate $[64,65]$. Overall, Sweden is described as country where both the legal and financial the incentives for employers to engage engage in sick-listed workers' RTW processes is comparatively weak [62]. The situation in Sweden can be contrasted with the Netherlands, where the employers are required to provide wage replacements for up to two years in the event of illness, and where they may be sanctioned when activities in RTW are considered insufficient [25]. In Canada where the compensation system in general is funded by employers via premiums, financial rebates are given to employers who can 
demonstrate fewer than expected days of sickness absence due to work injury and surcharges for a higher number of work injury absences days than expected [66]. These so called experience-rated premiums are assumed to encourage employers to undertake a preventive work to reduce injuries and the duration of sick leave absences. Meanwhile, studies have shown how financial incentives may result in employers becoming more selective when hiring new employees [67]. As a consequence, this might limit the possibility of workers with reduced work ability to enter the labour market and find a new job. Other studies have pointed out how employers use different strategies to avoid RTW obligations, such as accommodating the worker [68].

\subsection{Methodological Considerations}

A strength of this study is that matched pairs of workers and supervisors were sampled. This has made it possible to capture views and experiences regarding the cases from two different perspectives, which provides an analytical advantage. A potential limitation is that the study focused on workers who were sick-listed for more than 60 days, and this might have influenced the focus on transition rather than RTW in the cases analysed. Another potential factor that might have an impact on employers' role and activities in RTW is the worker's diagnosis. A majority of sick-leave cases were identified by employer and union organizations. Against this background, it is possible that the cases were considered to be the most successful ones (those put forward by employers) or the most difficult ones (those put forward by unions). Another possible limitation is that the interviews conducted with matched pairs might have influenced how open the participants were during the interviews; they might have been concerned about data security and remaining anonymous. The credibility of the study is strengthened by the discussions and examinations of the co- 
authors during the analytical process. Emerging findings of the study were systematically discussed among the authors, in order to achieve trustworthiness.

\section{Conclusions}

In this study the organizational response of employers to sick-listed workers was characterized by an economic perspective; it was the needs and interests of their business that guided their role and activities regarding RTW. The ability and willingness of employers to take social responsibility for sick-listed workers' RTW depended to a large extent on how valued the sick-listed workers were considered to be to their business and the nature of the job. The results of this study suggest that Swedish legislation and policies does not always adequately prompt employers to get sick-listed workers back to work. By highlighting cases where the outcomes of an RTW process to a large extent depended on the worker's value to the employer and the nature of the job, we call for further attention to the organizational conditions for employers to take social responsibility for RTW in the context of business pressure and work intensification.

\section{Declarations of Interests}

The authors report no declarations of interests.

This work was supported by

- The Swedish Research Council for Health, Working Life and Welfare, grant no: 208-0812.

- The Canadian Institutes of Health Research (CIHR) grant FRN: 53909, Work Disability Prevention Strategic Training Program 


\section{References}

1.

Waddell G, Burton A K. Is Work Good for Your Health and Wellbeing? The Stationery Office, 2006.

2. Immervoll H. Activation Policies in OECD Countries: An Overview of Current Approaches. 2012.

3. MacEachen E, Ferrier S, Kosny A, Chambers L. A deliberation on "hurt versus harm" logic in early return to work policy. Policy and Practice in Health and Safety. 2007;5(2):41-62.

4. Van Berkel R, Hornemann Møller, I. Active social policies in the EU: Inclusion through participation? Glasgow: Policy Press 2003.

5. Kuoppala J, Lamminpaa A. Rehabilitation and work ability: a systematic literature review. Journal of Rehabilitation Medicine. 2008;40(10):796-804.

6. Franche R-L, Cullen K, Clarke J, Irvin E, Sinclair S, Frank J et al. Workplace-based return-to-work interventions: a systematic review of the quantitative literature. Journal of Occupational Rehabilitation. 2005;15(4):607-31.

7. Krause N, Dasinger L K, Neuhauser F. Modified work and return to work: a review of the literature. Journal of Occupational Rehabilitation 1998;8(2):113-39.

8. Shaw W, Robertson MM, McLellan RK, Verma S, Pransky G. A controlled case study of supervisor training to optimize response to injury in the food processing industry. Work. 2006;26(2):107-14

9. Hees HL, Nieuwenhuijsen K, Koeter MWJ, Bültmann U, Schene AH Towards a New Definition of Return-to-Work Outcomes in Common Mental Disorders from a Multi-Stakeholder Perspective. PLOS ONE 2012;7(6):1-7.

10. Loisel P, Buchbinder R, Hazard R, Keller R, Scheel I, van Tulder M, Webster B. Prevention of work disability due to musculoskeletal disorders: the challenge of implementing evidence. Journal of Occupational Rehabilitation 2005;15(4):507-24.

11. Haafkens JA, Kopnina H, Meerman M G M, Van Dijk, F J H. Facilitating Job Retention for Chronically III Employees: Perspectives of Line Managers and Human Resource Managers. BMC Health Services Research 2011;11(104).

12. Holmgren K, Ivanoff S D. Supervisors' views on employer responsibility in the return to work process. A focus group study. Journal of Occupational Rehabilitation 2007 17(1):93-106.

13. Lemieux $P$, Durand $M$, Hong $Q N$. Supervisors' perception of the factors influencing the return to work of workers with common mental disorders. Journal of Occupational Rehabilitation. 2011;21(3):293-303.

14. Nieuwenhuijsen K, Verbeek J H A M, De Boer A G E M, Blonk R W B, Van Dijk F J H. Supervisory behavior as a predictor of return to work in employees absent from work due to mental health problems. Occupational and Environmental Medicine. 2004;61(10):817-23.

15. Tjulin Å, MacEachen E, Ekberg K. Exploring workplace actors' experiences of the social organization of return-to-work. Journal of Occupational Rehabilitation. 2009;20(3):311-21.

16. Dunstan D, MacEachen E. Bearing the brunt: Co-workers' experiences of work reintegration processes. Journal of Occupational Rehabilitation. 2013;23(1):44-54.

17. Tjulin $\AA$, MacEachen E, Stiwne E E, Ekberg K. The social interaction of return to work explored from co-workers' experiences. Disability and Rehabilitation. 2011;33(21-22):1979-89.

18. Wynne-Jones G, Buck R, Porteous C, Cooper L, Button L A, Main C J. What happens to work if you're unwell? beliefs and attitudes of managers and employees with musculoskeletal pain in a public sector setting. Journal of Occupational Rehabilitation. 2011;21(1):31-42 

Mahood $Q$ and the Small Business Systematic Review Team. Workplace health understandings and processes in small businesses: A systematic review of the qualitative literature. Journal of Occupational Rehabilitation. 2010;20(2):180-98.

20. Schwartz MS, Archie B. Corporate social responsibility: A three-domain approach. Business Ethics Quarterly. 2003;13(4):503-30.

21. Social Security Act (2010).

22. Work Environment Act, (1977).

23. Work Environments Authority's Statute Book: work adjustments and rehabilitation (1994).

24. Iseskog T. Arbetsgivarens rehabiliteringsansvar [The employer's rehabilitation responsibility]. Mölnlycke: Norsteds Juridik AB; 2009.

25. Lippel K, Lötters F. Public insurance systems: a comparison of cause - based and disability-based income support systems. In: Loisel P, Anema H, editor. Handbook of Work disability: Prevention and Management: Springer 2013.

26. Bengtsson $M$, Berglund $T$. Labour Market Policies in Transition: From Social Engineering to Standby-Ability. In: Larsson B, Letell M, Thörn H, editor. Transformation of the Swedish Welfare State From Social Engineering to Governance. Basingstoke: Palgrave; 2012.

27. Hetzler A. Labor Market Activation Policies for the Long Term III - A Sick Idea? European Journal of Social Security. 2010;11(4):369-403.

28. Socialförsäkringsutredningen P. Sveriges socialförsäkringar i jämförande perspektiv En institutionell analys av sjuk-, arbetsskade- och arbetslöshetsförsäkringarna i 18 OECD-länder 1930 till 2010 [Sweden's social insurances in a comparative perspective: An institutional analysis of the sickness-, workplace injury- and unemployment insurance in 18 OECD-contries 1930 until 2010]. Stockholm: Statens offentliga utredningar 2010.

29. Proposition. En reformerad sjukskrivningsprocess för ökad återgång $\mathrm{i}$ arbete [A reformed sick-leave process for increased return to work] 2007/08:136.

30. SOU. Mera försäkring och mera arbete [More insurance and more work]. Stockholm: Ministry of Health and Social Affairs 2006:86.

31. Ståhl C, Müssener $U$, Svensson T. Implementation of standardized time limits in sickness insurance and return-to-work: Experiences of four actors. Disability and Rehabilitation. 2012;34(16):1404-11.

32. SSIA. Sjukfrånvarons utveckling - Delrapport 1, år 2014 [The development of sickness absence - report 1, year 2014]. Stockholm 2014 ISSN 1654-8574.

33. Ekberg K, Wåhlin C, Persson J, Bernfort L, Öberg B. Early and late return to work after sick leave - predictors in a cohort of sick-listed individuals with mental disorders. Submitted

34. Graneheim U, Lundman B. Qualitative content analysis in nursing research: concepts, procedures and measures to achieve trustworthiness. Nurse Education Today. 2004;24(2):209-30.

35. Patton MQ. Qualitative research \& evaluation methods. 3rd ed. London: SAGE; 2002.

36. Hsieh HF, Shannon S.E Three Approaches to Qualitative Content Analysis. Qualitative Health Research. 2005;15(9):1227-88.

37. Lindqvist R. Att sätta gränser: organisationer och reformer $\mathrm{i}$ arbetsrehabilitering [Set limits: organizations and reforms in work rehabilitation]. Umeå: Boréa; 2002.

38. Eakin JM. Leaving it up to the workers: sociological perspectives on the management of health and safety in small workplaces. Int J Health Serv. 1992;22(4):689-704.

39. Eakin J, MacEachen E, Clarke J 'Playing it smart' with return to work: small workplace experience under Ontario's policy of self-reliance and early return. Policy and Practice in Health and Safety. 2003;1(2):19-42.

40. Seing I, Ståhl C, Nordenfelt L, Bülow P and Ekberg K. Policy and Practice of Work Ability. A Negotiation of Responsibility in Organizing Return to Work. Journal of Occupational Rehabilitation 2012;22(4):553-64. 
41. Kenny DT. Employers' perspectives on the provision of suitable duties in occupational rehabilitation. Journal of Occupational Rehabilitation. 1999;9(4):267-76.

42. Baril R, Berthelette D, Massicotte P. Early return to work of injured workers: multidimensional patterns of individual and organizational factors. Safety Science. 2003;41:277-300.

43. Burchell B, Ladipo D, Wilkingson F, editor. Job Insecurity and Work Intensification. London: Routledge; 2002.

44. Burke RJ, Cooper C L. The organization in crisis: downsizing, restructuring, and privatization. Oxford: Blackwell 2000.

45. Gowing MK, Kraft J D, Quick J C editor. The new organizational reality: downsizing, restructuring, and revitalization. Washington, DC: American Psychological Association 1997.

46. Gallie D, White M, Cheng Y, Tomlinson M. Restructuring the employment relationship Oxford: Clarendon Press; 1998.

47. Howard A. The changing nature of work. San Francisco: CA: Jossey-Bass; 1995.

48. Hood C. A public management for all seasons? Public Administration. 1991;69(1):3-19.

49. Hughes OE. Public management and administration: an introduction. New York Palgrave; 2003.

50. Pollitt C, Bouckaert G. Public Management Reform. 2nd ed. New York Oxford University Press; 2004.

51. Vahtera J, Kivimäki M, Pentti J, Theorell T. Effect of change in the psychosocial work environment on sickness absence: A seven year follow up of initially healthy employees. Journal of Epidemiology and Community Health. 2000;54(7):484-93.

52. Vahtera J, Kivimäki M, Pentti J. Effect of organisational downsizing on health of employees. Lancet. 1997;350(9085):1124 - 8.

53. Anderson N, Schalk, R. The Psychological Contract in Retrospect and Prospect. Journal of Organizational Behavior 1998;19:637-47.

54. Conway N, and Briner R B. Understanding Psychological Contracts at Work: a Critical Evaluation of Theory and Research. . New York: Oxford University Press; 2005.

55. Seing I, MacEachen E, Ståhl C, Ekberg K. Early-Return-to-Work in the Context of an Intensification of Working Life and Changing Employment Relationships. Journal of Occupational Rehabilitation. 2014;DOI 10.1007/s10926-014-9526-5.

56. Meyer J, Rowan B. Institutionalized Organizations: Formal Structure as Myth and Ceremony. American Journal of Sociology. 1977;83(2):340-63.

57. DiMaggio P. The Iron Cage Revisted; Institutionalized Isomorphism and Collective Identity in Organizational Fields. American Sociology Review. 1983;48(2):147-60.

58. Thedvall R. Rituals of Legitimation. Organising Accountability in EU Employment Policy. In: Boström M, Garsten, G, editor. Organizing Transnational Accountability Mobilization, Tools, Challenges. Cheltenham: Edward Elgar Publishing; 2008.

59. Westergård A. Arbetsgivarens ökade ansvar för sjuklön och rehabilitering kontra arbetstagarnas integritet - Går det att förena? [Employers' increased responsibility for sick pay and rehabilitation versus workers' integrity]. Uppsala: 2008.

60. Ståhl C. Samverkan kring återgång i arbete: var är arbetsgivarna? [Cooperation on return to work: where are the employers?]. Socialmedicinsk Tidskrift. 2009;86(3):265-74.

61. Melén D. Med arbetsförmåga, utan anställningsbarhet [With work ability, without employability]. Socialmedicinsk Tidskrift. 2009;86(3):265-74.

62. OECD. Sickness, disability and work: Breaking the barriers. Sweden: Will the Recent Reforms Make it? 2009.

63. SOU. Fokus på åtgärder - En plan för effektiv rehabilitering i arbetslivet [Focus on measures - A plan for an effective rehabilitation in working life] Stockholm: Ministry of Health and Social Affairs; 2006.

64. Bergendorff S. Rehabilitering - ett långt lidandes historia [Rehabilitation - a long history of suffering]. Sverige 2006. 
65

Riksrevisionen. Tas sjukskrivnas arbetsförmåga tillvara? Försäkringskassans kontakter med arbetsgivare [Is the sick-listed workers' work ability concidered? The Swedish Social Insurance Agency's contacts with employers]. Stockholm 2007.

66. Mansfield L, MacEachen, E., Tompa, E., Kalcevich, C.A Critical review of literature on experience-rating in workers' compensation systems. Policy and Practice in Health and Safety 2012;10(1):3-25.

67. van Oorschot W BK. The Battle Against Numbers: Disability Policies in the Netherlands. European Journal of Social Security. 2000;2(4):343-61.

68. MacEachen E, Kosny A, Ferrier S. and Chambers L. The "toxic dose" of system problems: Why some injured workers don't return to work as expected. Journal of Occupational Rehabilitation. 2010;20(3):349-66. 


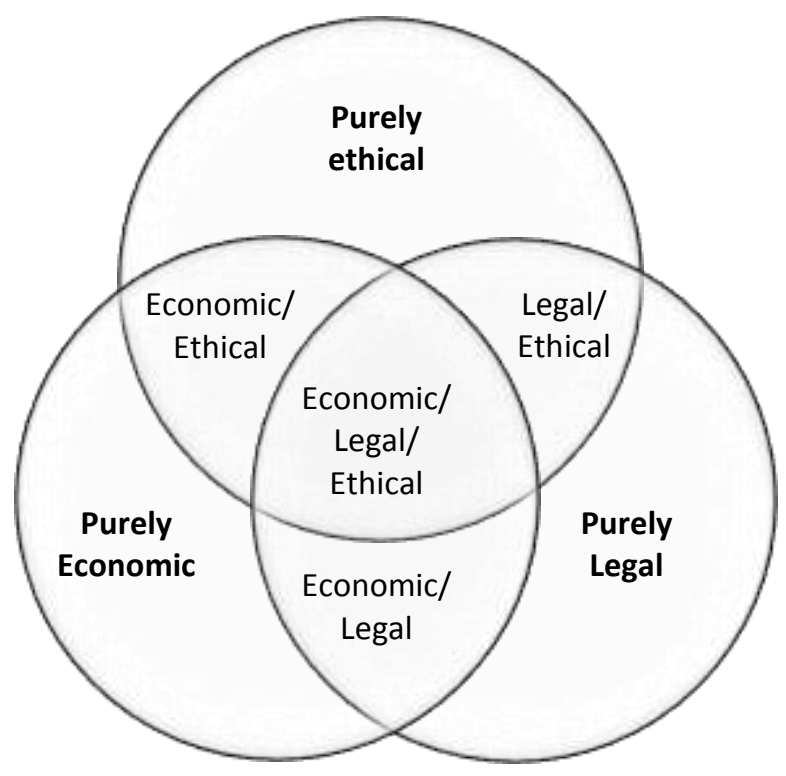

Figure 1: The Three-Domain Model of Corporate Social Responsibility 
Figure 2: The relative influence of economic, legal and ethical considerations in employers' activities in RTW.

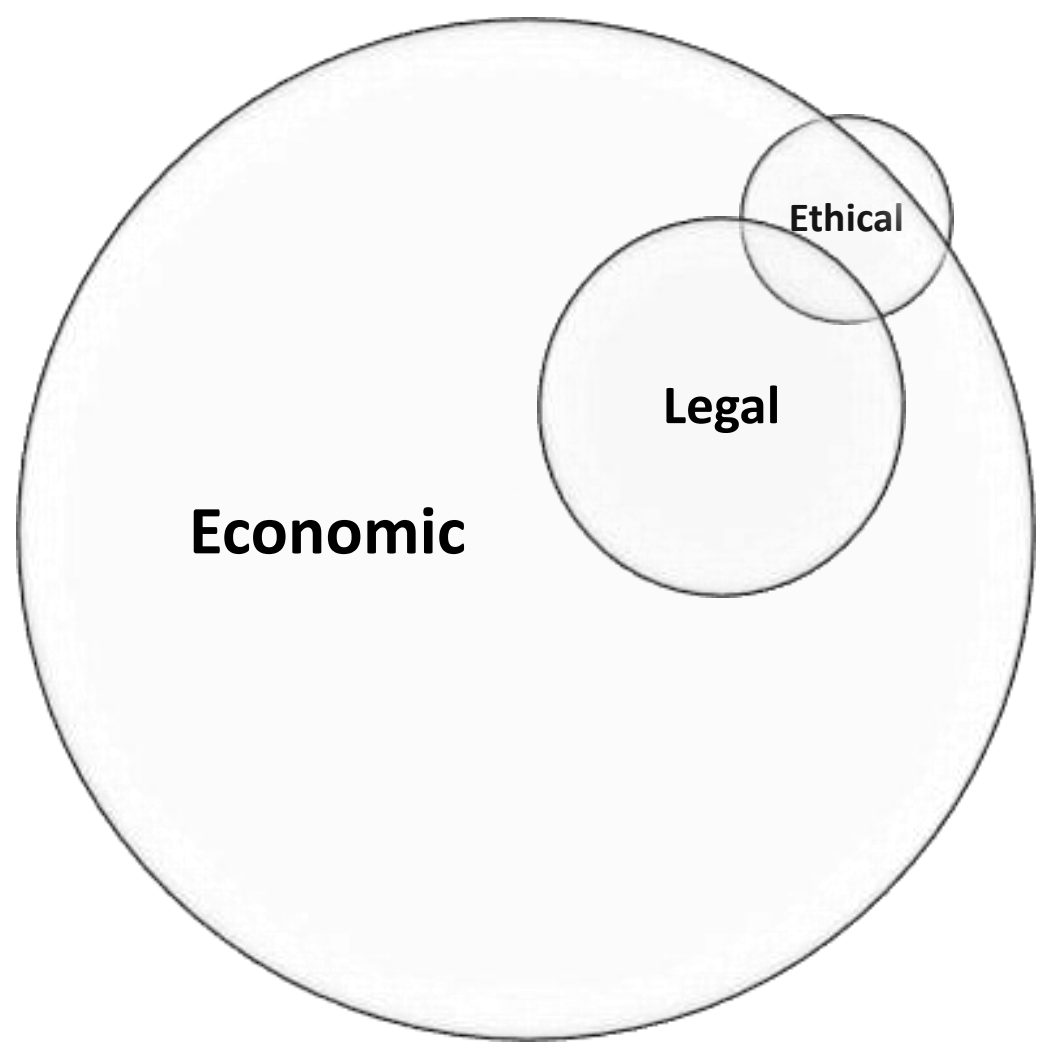


Table 1

Description of the participants in the study

\begin{tabular}{|l|l|l|l|}
\hline Case & Work Organization & $\begin{array}{l}\text { Worker } \\
\text { (gender, occupation) } \\
\text { Male, Engineering/site } \\
\text { manager }\end{array}$ & $\begin{array}{l}\text { Manager } \\
\text { (gender, occupation) }\end{array}$ \\
\hline $\mathbf{1}$ & $\begin{array}{l}\text { Private Unit manager } \\
\text { (Transport, infrastructure) }\end{array}$ & Male, Legal specialist & Female, Unit manager \\
\hline $\mathbf{2}$ & Public authority & $\begin{array}{l}\text { Female, secondary school } \\
\text { teacher }\end{array}$ & Male, Principal \\
\hline $\mathbf{3}$ & High school (municipality) & Female, Unit manager \\
\hline $\mathbf{4}$ & Hospital (County council) & Female, Assistant nurse & Femanger \\
\hline $\mathbf{5}$ & Public authority & Female, Public officer & Male, Unit manager \\
\hline $\mathbf{6}$ & Hospital (County council) & Female, Assistant nurse & Female, Unit manager \\
\hline $\mathbf{7}$ & $\begin{array}{l}\text { Telecom company (Owned } \\
\text { by municipality) }\end{array}$ & Female, Administrator & Male, Managing director \\
\hline $\mathbf{8}$ & Elderly care (Municipality) & Female, Assistant nurse & Female, Unit manager \\
\hline $\mathbf{9}$ & Elderly care (Municipality) & Female, Assistant nurse & Female, Unit manager \\
\hline $\mathbf{1 0}$ & Public authority & Female, Public officer & Female, Unit manager \\
\hline $\mathbf{1 1}$ & Elderly care (Municipality) & Female, Assistant nurse & Female, Unit manager \\
\hline $\mathbf{1 2}$ & Elderly care (Municipality) & Female, Assistant nurse & Female, Unit manager \\
\hline $\mathbf{1 3}$ & Municipality & Female, Public officer & Female, Unit manager \\
\hline $\mathbf{1 4}$ & Elderly care (Municipality) & Female, Assistant nurse & Female, Unit manager \\
\hline $\mathbf{1 5}$ & Private bus company & Female, Bus driver & Male, Unit manager \\
\hline $\mathbf{1 6}$ & Elderly care (Municipality) & Female, Assistant nurse & Female, Unit manager \\
\hline $\mathbf{1 7}$ & Social care (Municipality) & Female, Assistant nurse & Male, Unit manager \\
\hline $\mathbf{1 8}$ & Public authority & Female, Public officer & Female, Unit manager \\
\hline
\end{tabular}




\section{Implications for Rehabilitation}

- Employers may have difficulties in taking social responsibility for RTW when economic considerations regarding their business take precedence over legal and ethical considerations.

- Rehabilitation professionals should be aware of that outcomes of an RTW process can be influenced by the worker's value to the employer and the nature of the job (e.g. availability of suitable work adjustments). 'Low-value' workers at workplaces with limited possibilities to offer workplace adjustments may run a high risk of dismissal.

- Swedish legislation and policies may need reforms to put more pressure on employers to promote RTW. 